\title{
Subunit Structure of Soybean 11S Globulin
}

\author{
Keisuke Kitamura, Toshio Takagi* and Kazuo Shibasaki \\ Faculty of Agriculture, Department of Food Chemistry, \\ Tohoku University, Sendai, Miyagi 980 \\ *Institute for Protein Research, Osaka University, Suita 565
}

Received April 23, 1976

\begin{abstract}
The acidic and the basic subunits were shown to be present in equimolar amounts in the 11S globulin molecule by the densitometric scanning of the SDS gel and the molecular weight consideration. The four acidic subunits $\left(A_{1}, A_{2}, A_{3}\right.$ and $\left.A_{4}\right)$ were found to be present in the approximate molar ratio of $1: 1: 2: 2$. Four basic subunits separated and designated as $\mathbf{B}_{1}, \mathbf{B}_{2}, \mathbf{B}_{3}$ and $\mathbf{B}_{4}$ based on the relative mobilities in the acidic gel in $7 \mathrm{M}$ urea were found to be present in the approximate molar ratio of $1: 1: 2: 2$. The four basic subunits were fractionated in approximately same amounts into three different peaks, peak $I$ $\left(B_{1}\right.$ and $\left.B_{2}\right)$, peak II $\left(B_{3}\right)$ and peak III $\left(B_{4}\right)$ by CM-Sephadex $C-50$ column chromatography in the presence of $6 \mathrm{M}$ urea. Three kinds of intermediary subunits of $11 \mathrm{~S}$ globulin were fractionated with DEAE-Sephadex A-50 in the absence of reducing agents in $6 \mathrm{M}$ urea, and disulfide bonds appeared to participate in the binding between the acidic and the basic subunits in the molar ratio of 1:1 with the following combinations; $A_{1}$ and $A_{2}$ combined with $\mathbf{B}_{3}, \mathbf{A}_{3}$ with $\mathbf{B}_{1}$ and $\mathbf{B}_{2}$, and $\mathbf{A}_{4}$ with $\mathbf{B}_{4}$. In view of the above results and molecular weight consideration, a new model of subunit structure was proposed for $11 \mathrm{~S}$ globulin.
\end{abstract}

Catsimpoolas et al. ${ }^{1)}$ reported that $11 \mathrm{~S}$ globulin which is one of the main storage proteins in soybean seed consisted of the three kinds of acidic and the three kinds of basic subunits. However, Kitamura and Shibasaki ${ }^{27}$ recently revealed that the four kinds of acidic subunits and at least three kinds of basic subunits of $11 \mathrm{~S}$ globulin were separated by the disc electrophoresis in $7 \mathrm{M}$ urea, and the former subunits were isolated with DEAESephadex A-50 in the presence of $6 \mathrm{M}$ urea. However, neither each acidic nor each basic subunit was present in equimolar amounts as estimated from the densitometric scanning of amido black 10 stain. A subunit composition of $11 \mathrm{~S}$ globulin is still not clear.

In the present investigation, a modified procedure of the previous method ${ }^{3)}$ has been used for a purification of $11 \mathrm{~S}$ globulin. The

* A part of this study was made at Institute for Protein Research.

Abbreviations: SDS, sodium dodecyl sulfate; 2ME, 2-mercaptoethanol; EDTA, ethylenediaminetetraacetic acid; CAM-11S, nonreduced S-carboxyamidemethylated 11S globulin; RCAM-11S, reduced S-carboxyamidemethylated $11 \mathrm{~S}$ globulin; IS, intermediary subunit. subunit composition of $11 \mathrm{~S}$ globulin has been investigated by ion exchange column chromatography in the presence of $6 \mathrm{M}$ urea, SDS gel electrophoresis, the disc and the acidic gel electrophoresis in $7 \mathrm{M}$ urea. Further, fractionation of intermediary subunits of $11 \mathrm{~S}$ globulin has been done with DEAE-Sephadex A-50 in the absence of reducing agents in $6 \mathrm{M}$ urea. In order to prevent sulfhydryl-disulfide exchange reactions during the fractionation, all free sulfhydryl groups in 11S globulin were blocked with iodoacetoamide in the presence of urea. Combinations between the acidic and the basic subunits were revealed by SDS gel and the acidic gel electrophoresis in $7 \mathrm{M}$ urea after treatment of the fractionated intermediary subunits with 2-mercaptoethanol(2ME) in the presence of urea or SDS. The data obtained led us to present a subunit structure of $11 \mathrm{~S}$ globulin.

\section{MATERIALS}

Soybean (var. Raiden) harvested at Furukawa, Miyagi, Japan in 1974 was used throughout this work. Urea used for electrophoresis was specially prepared 
reagent for biochemical research purchased from Nakarai Chemicals Ltd. All the other reagents were the highest grade. ConA-Sepharose 4B, Sepharose 6B, DEAE-Sephadex A-50 and CM-Sephadex C-50 were obtained from Pharmacia.

\section{METHODS}

Preparation of Wolf's fraction VI. Ten grams of defatted soybean meal were suspended in $1000 \mathrm{ml}$ of $0.065 \mathrm{M} \mathrm{NaCl}$ solution containing $0.01 \mathrm{M}$ 2-ME, adjusted to $\mathrm{pH} 8.0$ with $1 \mathrm{~N} \mathrm{NaOH}$. The solution was filtered through several layers of gauze and then centrifuged. The supernatant was adjusted to $\mathrm{pH} 6.3$ with $1 \mathrm{~N} \mathrm{HCl}$, stirred for $15 \mathrm{~min}$ and centrifuged. The above procedures were performed at $5^{\circ} \mathrm{C}$. The precipitate (Okubo's crude $11 \mathrm{~S}$ globulin) ${ }^{4}$ was subjected to ammonium sulfate fractionation to prepare "fraction VI" described by Wolf et al. ${ }^{3}$ The precipitation procedure at pH 4.0 between 26 and $40 \%$ saturation was omitted, since proteins $(2 \mathrm{~S}, 15 \mathrm{~S}$ and $>15 \mathrm{~S}$ proteins) removed by this precipitation could be readily removed by a gel filtration with Sepharose $6 \mathrm{~B}$.

Purification of $11 \mathrm{~S}$ globulin. Twenty $\mathrm{ml}$ of the fraction VI (about $2 \%$ protein concentration) in the $\mathrm{pH} 7.6$ standard buffer containing $0.1 \% \mathrm{NaN}_{3}$ was applied on a ConA-Sepharose $4 \mathrm{~B}$ column $(2.2 \times 25 \mathrm{~cm})$ equilibrated with the buffer and eluted at a flow rate of $10 \mathrm{ml}$ per hour with the same buffer. After nonadsorbed fraction eluted, $30 \mathrm{ml}$ of the buffer containing $0.1 \mathrm{M} \alpha$-methyl-D-mannoside was added to the column and washed with the first buffer to elute adsorbed fraction. The non-adsorbed fraction was concentrated by ultrafiltration and chromatographed on a Sepharose $6 \mathrm{~B}$ column. For further purification, ion exchange chromatography was performed, because faint bands which were unlikely to be subunit bands of $11 \mathrm{~S}$ globulin were observed on a SDS gel of the 11S globulin purified with ConA-Sepharose $4 \mathrm{~B}$ and Sepharose $6 \mathrm{~B}$ from the fraction VI. The eluate in the main peak on the Sepharose $6 \mathrm{~B}$ column was concentrated and dialyzed against $0.035 \mathrm{M}$ phosphate buffer ( $\mathrm{pH} 7.6)$ containing $0.2 \mathrm{M} \mathrm{NaCl}$ and $0.01 \mathrm{M} \mathrm{2-ME}$, and then applied on a DEAE-Sephadex A-50 column equilibrated with the buffer. Ionic strength gradient elution was achieved by adding $0.5 \mathrm{M} \mathrm{NaCl}$ solution to a mixing chamber containing $500 \mathrm{ml}$ of the buffer.

Preparation of CAM-IIS. $100 \mathrm{mg}$ of the lyophilized 11S globulin was dissolved in $0.15 \mathrm{M}$ tris- $\mathrm{Cl}(\mathrm{pH}$ 8.6) in the presence of $8 \mathrm{M}$ urea and $1 \mathrm{~mm}$ EDTA to a protein concentration of $1 \%$ under nitrogen gas. A small amount of undissolved materials was centrifuged off. The carboxyamidemethylation of free sulfhydryl groups in the protein was performed by adding $0.135 \mathrm{~g}$ of iodoacetoamide in the dark for $15 \mathrm{~min}$. The modified protein was dialyzed against deionized water in the dark and lyophilized.

Electrophoresis of subunit. SDS gel electrophoresis was performed according to the method of Weber and Osborn $^{0)}$ on $10 \%$ polyacrylamide gel. Molecular weights of the intermediary subunits were estimated by SDS gel electrophoresis in the absence of reducing agents. The standard proteins (bovine serum albumin, catalase, $\gamma$-globulin and ovalbumin) were electrophoresed in the presence of reducing agents on SDS gels. The disc gel electrophoresis in $7 \mathrm{M}$ urea was performed according to the previous method. ${ }^{2)}$ Acidic gel electrophoresis in $7 \mathrm{M}$ urea was performed by using a $6.0 \times 100 \mathrm{~mm}$ glass tube in $10 \% \mathrm{CH}_{3} \mathrm{COOH}$ on $7.5 \%$ polyacrylamide gel. Gels were prepared as follows; for 10 gels, $5.0 \mathrm{ml}$ of acrylamide solution (acrylamide $30.0 \mathrm{~g}$, methylenebisacrylamide $0.8 \mathrm{~g}$, and water to $100 \mathrm{ml}$ ) were mixed with $2.0 \mathrm{ml} \mathrm{CH}_{3} \mathrm{COOH}, 4.0 \mathrm{ml}$ of $5 \% \mathrm{~N}, \mathrm{~N}, \mathrm{~N}^{\prime}, \mathrm{N}^{\prime}$,-tetramethylethylenediamine and $1.4 \mathrm{ml}$ of water, and $8.4 \mathrm{~g}$ of urea was dissolved. After deaeration, $2.0 \mathrm{ml}$ of ammonium persulfate $(10.5 \mathrm{mg}$ per $\mathrm{ml})$ was added. After further deaeration, each tube was filled with the solution up to $1 \mathrm{~cm}$ from the top of the tube. The gel was solidified after layering water on the top of the gel solution within a half hour at $25^{\circ} \mathrm{C}$. Preelectrophoresis was carried out to remove excess ammonium persulfate and to get a constant resistance inside the gels. Electrophoresis was performed for $3.0 \mathrm{hr}$ at a constant voltage of $150 \mathrm{~V}$ in $10 \%$ acetic acid. All gels were stained with Coomasie Blue and destained by diffusion in $7.5 \%$ $\mathrm{CH}_{3} \mathrm{COOH}-5 \% \mathrm{CH}_{3} \mathrm{OH}$-water.

Ion exchange chromatography of subunit. DEAESephadex A-50 column and CM-Sephadex C-50 column chromatography were performed using $2.0 \times$ $25 \mathrm{~cm}$ column in $0.12 \mathrm{M}$ sodium phosphate buffer (pH 6.5) and in $0.09_{\mathrm{M}}$ sodium phosphate buffer $(\mathrm{pH}$ 6.7) respectively in the presence of $6 \mathrm{M}$ urea increasing the concentration of $\mathrm{NaCl}$ gradiently. A fractionation of the intermediary subunits was performed as follows; a column $(2.0 \times 25 \mathrm{~cm})$ was prepared with DEAESephadex A-50. $80 \mathrm{mg}$ of CAM-11S dissolved in about $5 \mathrm{ml}$ of $0.1 \mathrm{M}$ sodium phosphate buffer ( $\mathrm{pH} 6.5$ ) containing $1 \mathrm{~mm}$ EDTA and $6 \mathrm{M}$ urea was applied on the column equilibrated with the buffer. Ionic strength linear elution was achieved by adding $0.4 \mathrm{M}$ $\mathrm{NaCl}$ solution to a mixing chamber containing $500 \mathrm{ml}$ of the buffer. Fractions were monitored at $280 \mathrm{~nm}$.

\section{RESULTS}

\section{Purity of the purified $11 S$ globulin}

The underlined part of the elution profole 


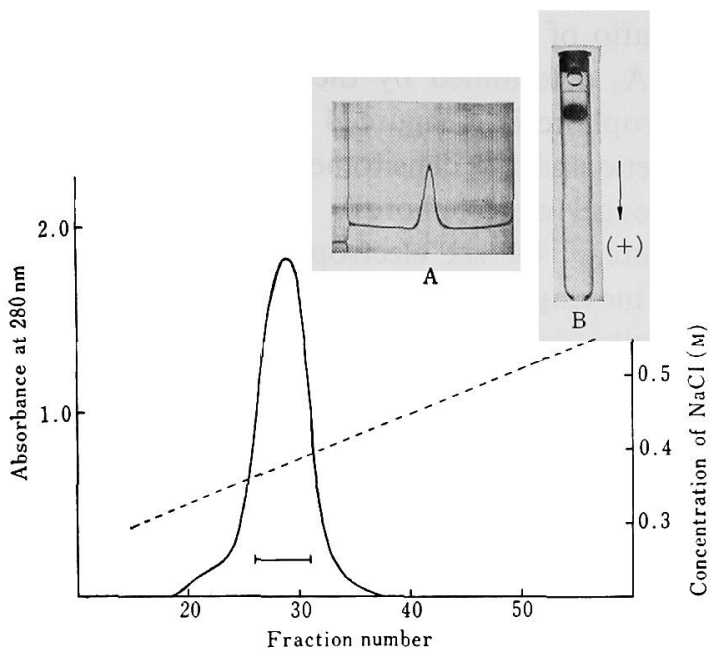

Fig. 1. DEAE-Sephadex A-50 Column Chromatogram of $11 \mathrm{~S}$ Globulin.

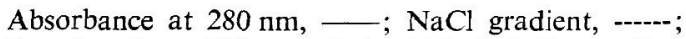
Sample, about $300 \mathrm{mg}$ of the $11 \mathrm{~S}$ globulin purified with ConA-Sepharose $4 \mathrm{~B}$ and Sepharose $6 \mathrm{~B}$ from the Wolf's fraction VI; Column size, $2.5 \times 30 \mathrm{~cm}$; Flow rate, $12 \sim 15 \mathrm{ml}$ per hour; Volume of fraction, $9.4 \mathrm{ml}$; Temperature, $5^{\circ} \mathrm{C}$; Elution, $0.035 \mathrm{M}$ potassium phosphate buffer ( $\mathrm{pH} 7.6$ ) with $0.2 \mathrm{M} \mathrm{NaCl}$ and $0.01 \mathrm{M} 2-\mathrm{ME}$ containing $\mathrm{NaCl}$ in gradient concentration of 0 to $0.75 \mathrm{M}$. Insets are sedimentation pattern (A) and polyacrylamide gel electrophoretic pattern (B) of the underlined part. Sedimentation is from left to right after $40 \mathrm{~min}$ at $52,000 \mathrm{rpm}$, at $0.7 \%$ protein concentration. The gel and electrode buffers were $0.035 \mathrm{M}$ potassium phosphate buffer $(\mathrm{pH}$ 7.6). Electrophoresis was carried out for $3.5 \mathrm{hr}$ at $4 \mathrm{~mA}$ per a gel $(6.5 \%$ gel $)$.

shown in Fig. 1 on the DEAE-Sephadex A-50 column was obtained as a purified $11 \mathrm{~S}$ globulin. In the ultracentrifuge, a single symmetrical sedimentation peak was obtained and a single electrophoretic band was observed by the disc gel electrophoresis in $0.035 \mathrm{M}$ phosphate buffer ( $\mathrm{pH}$ 7.6). However, the faint bands which represented less than $1 \sim 2 \%$ of the total bands and were unlikely to be subunit bands of $11 \mathrm{~S}$ globulin were also observed on the SDS gel of the purified 11S globulin. The faint bands may be contaminants attached to $11 \mathrm{~S}$ protein in the mild buffers. A similar observation was also presented by Catsimpoolas et al. ${ }^{7}$

\section{Electrophoresis of subunit}

The electrophoretic and the densitometric patterns of the SDS gel electrophoresis of RCAM-11S shown in Fig. 2 show that the areas under the densitometric peak I, II and III are approximately $2: 2: 1$. The previous results $^{2)}$ showed that the peak I, II and III corresponded to the total basic subunits (MW 22,500), $A_{1}, A_{2}$ and $A_{3}$ subunits ( $M W$ 37,000) and $A_{4}$ subunit (MW 45,000) respectively. Thus, the above results indicates that

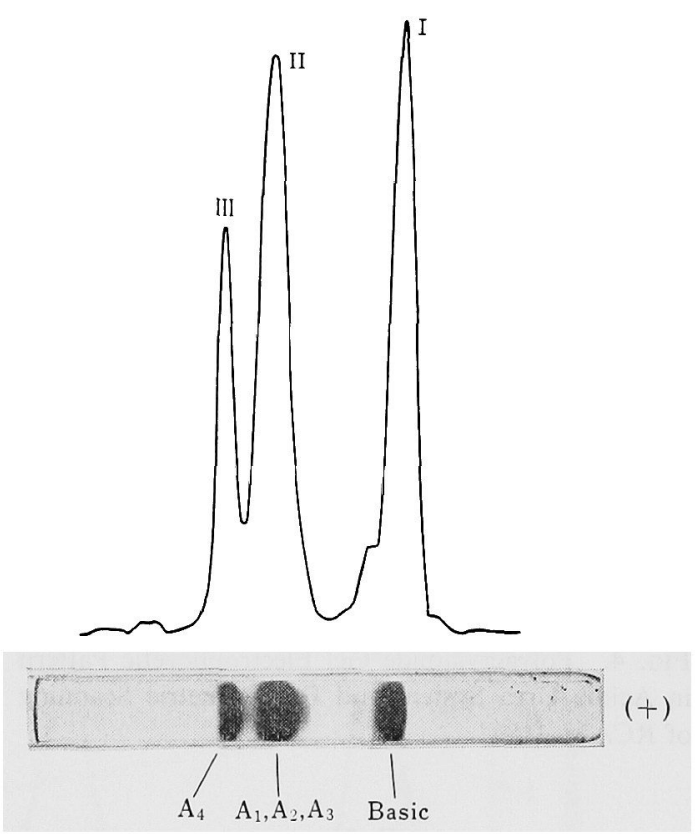

FIG. 2. SDS Gel Electrophoretic Pattern and Densitometric Scanning of RCAM-11S.

Densitometric scanning was obtained with a Beckman ACTA CIII UV Visible spectrophotometer.

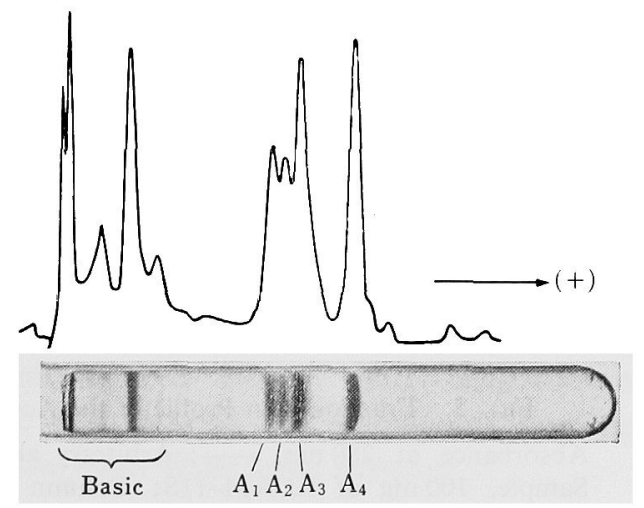

FIG. 3. Disc Electrophoretic Pattern in Alkaline Urea System and Densitometric Scanning of RCAM$11 \mathrm{~S}$. 
the molar ratio of the total basic to the total acidic subunits in the $11 \mathrm{~S}$ globulin molecule is approximate $1: 1$. The densitometric scanning of the disc gel electrophoresis of RCAM$11 \mathrm{~S}$ in $7 \mathrm{M}$ urea shown in Fig. 3 shows that the four acidic subunits $\left(\mathrm{A}_{1}, \mathrm{~A}_{2}, \mathrm{~A}_{3}\right.$ and $\left.\mathrm{A}_{4}\right)$ occur in the stoichiometric proportions: $1: 1$ : $2: 2$. This ratio is in a good agreement with

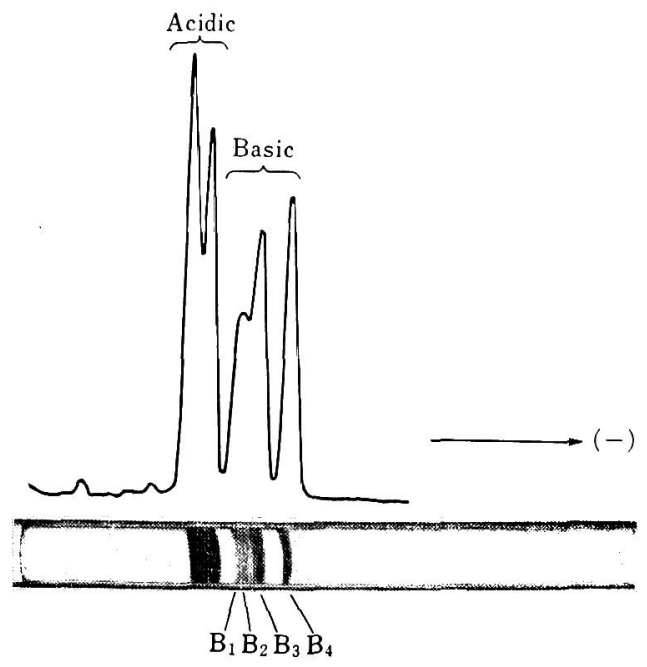

FIG. 4. Polyacrylamide Gel Electrophoretic Pattern in Acidic Urea System and Densitometric Scanning of RCAM-11S. the ratio of $A_{4}$ to the total amount of $A_{1}, A_{2}$ and $A_{3}$ determined by the result of SDS gel electrophoresis. Figure 4 shows the electrophoretic and the densitometric patterns of the acidic gel electrophoresis of RCAM-11S in $7 \mathrm{M}$ urea. Of six electrophoretic bands, the fast moving bands consisted of four basic subunits designated as $\mathbf{B}_{1}, \mathbf{B}_{2}, \mathbf{B}_{3}$ and $\mathbf{B}_{4}$ subunit based on these relative mobilities, the slow moving bands consisted of the acidic subunits. The four basic subunits $\left(\mathbf{B}_{1}, \mathbf{B}_{2}\right.$, $B_{3}$ and $B_{4}$ ) exist in the approximate molar ratio of $1: 1: 2: 2$ in the $11 \mathrm{~S}$ globulin molecule.

\section{Fractionation of subunit}

The fractionation profile of the acidic subunits was illustrated in Fig. 5. It can be seen from the electrophoretic patterns of the fractions that $A_{1}$ and $A_{2}$ elute in peak II, $A_{3}$ in peak III and $A_{4}$ in peak IV. Each peak area under the three peaks monitored at $280 \mathrm{~nm}$ and at $750 \mathrm{~nm}$ (the Folin-Lowry reaction $^{81}$ ) is approximately equivalent. This ratio is in a good agreement with the ratio of the total amount of $A_{1}, A_{2}, A_{3}$ and to $A_{4}$ subunit determined by the densitometric scanning of the disc gel electrophoresis of

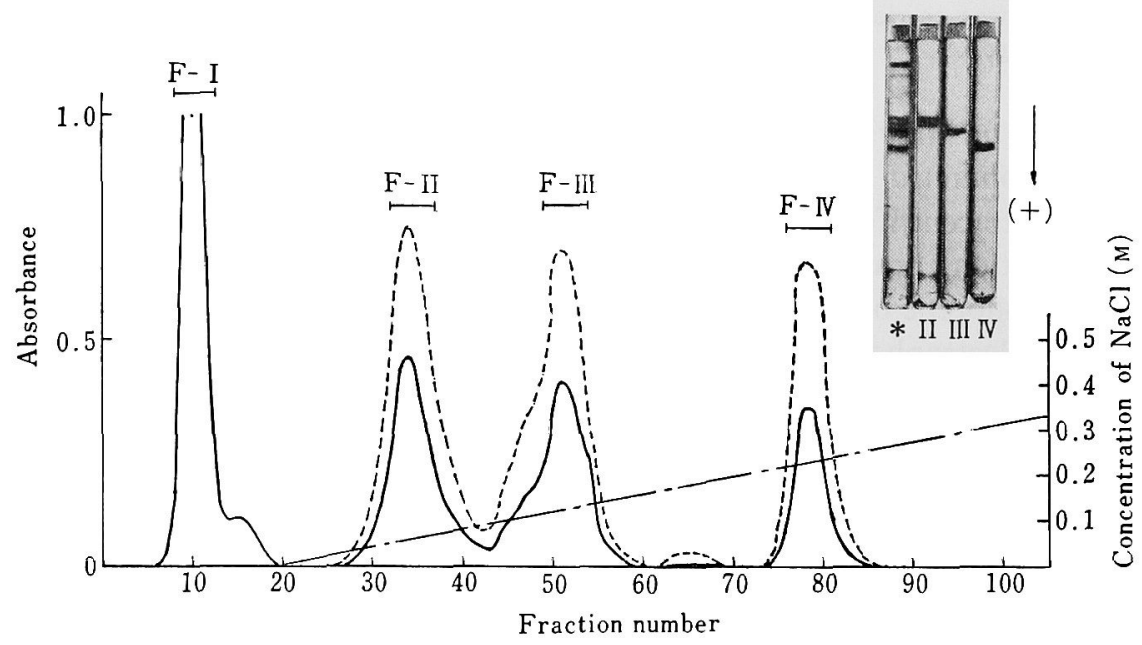

FIG. 5. Fractionation Profile of the Acidic Subunits with DEAE-Sephadex A-50 in Urea.

Absorbance at $280 \mathrm{~nm}$, —- Arbitrary absorbance at $750 \mathrm{~nm}$ (Folin-Lowry reaction), --.--; Sample, $100 \mathrm{mg}$ of RCAM-11S; Column size, $2.5 \times 25 \mathrm{~cm}$; Flow rate, $10 \sim 12 \mathrm{ml}$ per hour; Volume of fraction, $7.9 \mathrm{ml}$; Temperature, $5^{\circ} \mathrm{C}$; Elution, $0.12 \mathrm{~m}$ sodium phosphate buffer (pH 6.5) in the presence of $6 \mathrm{M}$ urea containing $\mathrm{NaCl}$ in gradient concentration of 0 to $0.4 \mathrm{M}$. Insets are electrophoretic patterns of RCAM-11S(*) and the fractions (F-II, III and IV) in the alkaline urea system. 


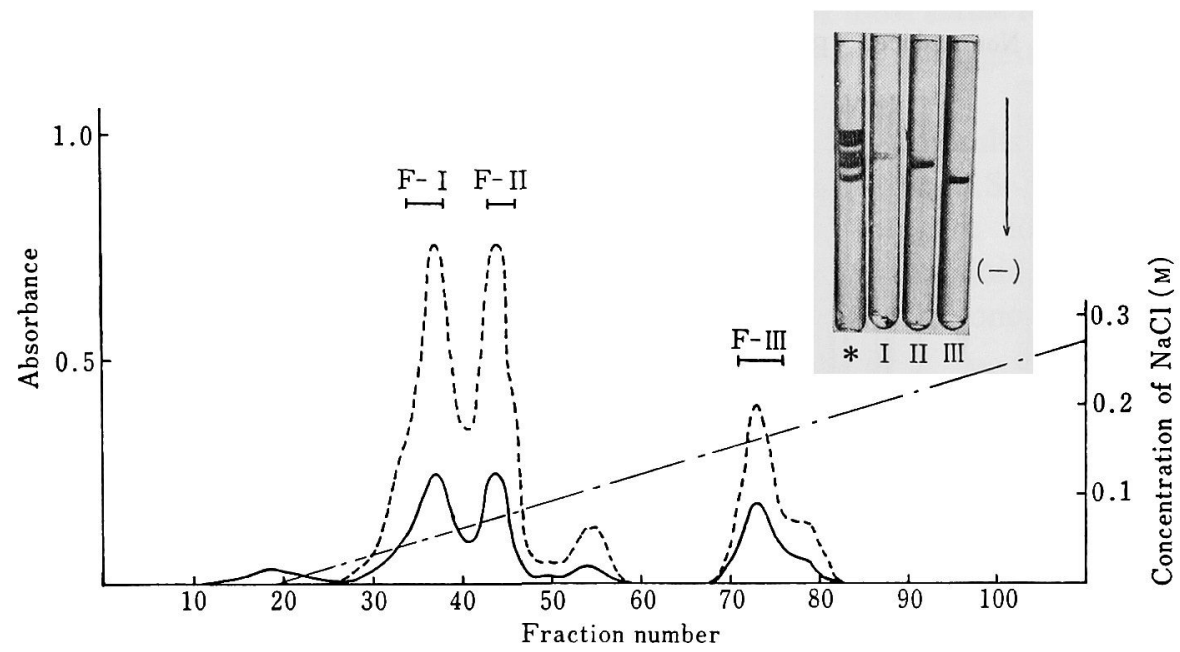

Fig. 6. Fractionation Profile of the Basic Subunits with CM-Sephadex C-50 in Urea.

Absorbance at $280 \mathrm{~nm}$, _- Arbitrary absorbance at $750 \mathrm{~nm},-.-$ - $_{\text {; }}$ Sample, the unadsorbed fraction (F-I in Fig. 5); Column size, $2.5 \times 25 \mathrm{~cm}$; Flow rate, $10 \sim 12 \mathrm{ml}$ per hour; Volume of fraction, $7.9 \mathrm{ml}$; Temperature, $5^{\circ} \mathrm{C}$; Elution, $0.09 \mathrm{M}$ sodium phosphate buffer $(\mathrm{pH} 6.7)$ in the presence of $6 \mathrm{M}$ urea containing $\mathrm{NaCl}$ in gradient concentration of 0 to $0.3 \mathrm{M}$. Insets are electrophoretic patterns of RCAM-11S(*) and the fractions (F-I, II and III) in the acidic urea system.

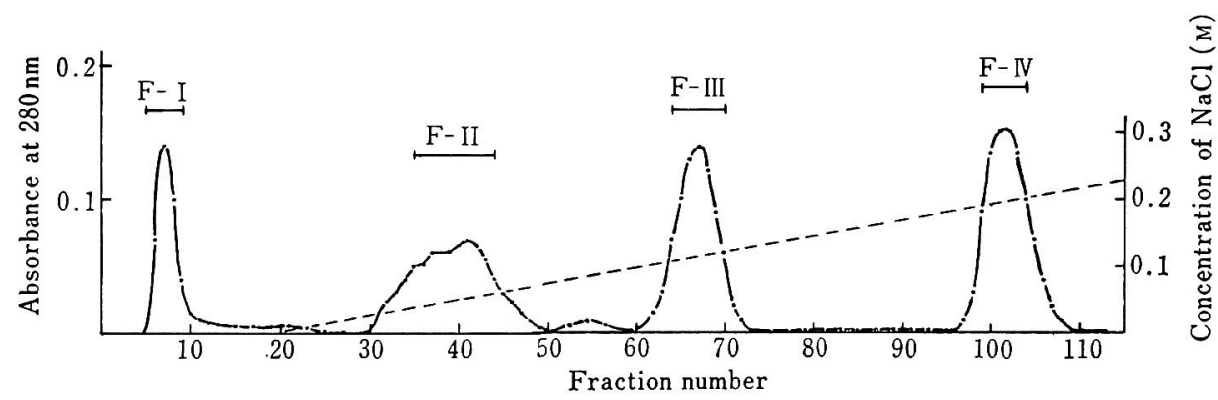

FIG. 7. Fractionation Profile of Intermediary Subunit of 11 S Globulin with DEAE-Sephadex A-50 in the Absence of Reducing Agents in Urea.

Absorbance at $280 \mathrm{~nm},-\bullet \mathrm{NaCl}$ gradient, -----; Sample, $80 \mathrm{mg}$ of CAM-11S; Column size, $2.5 \times 25 \mathrm{~cm}$; Flow rate, $10 \sim 12 \mathrm{ml}$ per hour; Volume of fraction, $6.0 \mathrm{ml}$; Temperature, $5^{\circ} \mathrm{C}$; Elution, $0.1 \mathrm{~m}$ sodium phosphate buffer $(\mathrm{pH} 6.5)$ in the presence of $6 \mathrm{~m}$ urea and $1 \mathrm{~mm}$ EDTA containing $\mathrm{NaCl}$ in gradient concentration of 0 to $0.4 \mathrm{M}$.

RCAM-11S in $7 \mathrm{M}$ urea. The fractionation profile of the basic subunits was illustrated in Fig. 6. It can be seen from the electrophoretic patterns shown in Fig. 6 that $B_{1}$ and $B_{2}$ elute in peak $I, B_{3}$ in peak II and $B_{4}$ in peak III. Each peak area under the three peaks monitored at $280 \mathrm{~nm}$ is approximately equivalent, and this ratio is in a good agreement with the molar ratio of the total amount of $B_{1}, B_{2}$, $B_{3}$ and to $B_{4}$ in the $11 \mathrm{~S}$ globulin molecule determined by the densitometric scanning of the acidic gel electrophoresis of RCAM-11S in $7 \mathrm{M}$ urea. But the peak area under peak III monitored at $750 \mathrm{~nm}$ is about a half of that under peak I and II respectively, and this result suggests that the amino acid composition of $\mathrm{B}_{4}$ subunit may be different from those of the other three basic subunits.

\section{Fractionation of intermediary subunit}

The fractionation profile of the intermediary subunits was illustrated in Fig. 7. Four 


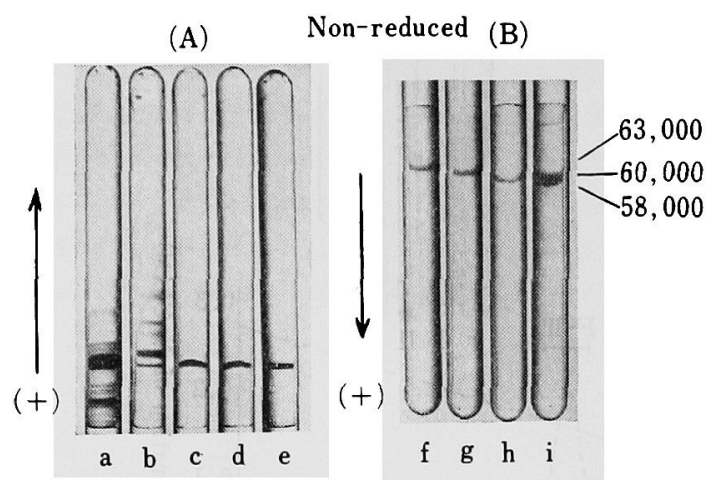

FIg. 8-A. Acidic Urea Gel Electrophoretic Patterns of Non-reduced CAM-11S and Non-reduced Fractions in Fig. 7.

CAM-11S (a), F-I (b), F-II (c), F-III (d) and F-IV (e).

FIG. 8-B. SDS Gel Electrophoretic Patterns of Nonreduced CAM-11S and Non-reduced Fractions in Fig. 7.

CAM-11S (i), F-II (h), F-III (g) and F-IV (f).

fractions (F-I, II, III and IV) were obtained and freeze-dried after dialysis against deionized water. Proteins eluted in F-II, III and IV gave one major electrophoretic band respectively both on the acidic gels in $7 \mathrm{M}$ urea (Fig. 8-A) and on the SDS gels (Fig. 8-B), and designated as IS-1, IS-2 and IS-3 respectively. IS-1, IS-2 and IS-3 migrated at relative mobilities corresponding to molecular weights of $58,000,60,000$ and 63,000 respectively on the SDS gels.

\section{Polypeptide composition of intermediary subunit}

The lyophilized intermediary subunits were dissolved in $0.2 \mathrm{M} 2-\mathrm{ME}$ solutions ( $\mathrm{pH} \mathrm{7 \sim 8)}$ in the presence of $8 \mathrm{M}$ urea or $0.1 \% \mathrm{SDS}$, and then applied on the acidic gels in $7 \mathrm{M}$ urea and on the SDS gels. It is observed from the electrophoretic patterns shown in Fig. 9 that IS-1 consists of $A_{1}, A_{2}$ and $B_{3}$, IS-2 consists of $A_{3}, B_{1}$ and $B_{2}$, and IS-3 consists of $\mathrm{A}_{4}$ and $\mathrm{B}_{4}$ with the approximate molar ratio of the total acidic to the total basic subunits of $1: 1$, respectively. Proteins in F-I may be mainly the basic subunits of which disulfide bonds between the acidic and the basic subunits have already been cleavaged

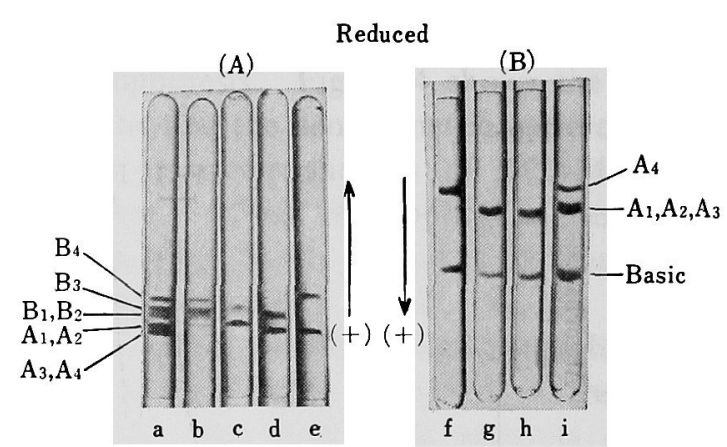

FIG. 9-A. Acidic Urea Gel Electrophoretic Patterns of RCAM-11S and Reduced Fractions in Fig. 7.

RCAM-11S (a), F-I (b), F-II (c), F-III (d) and F-IV (e).

FIG. 9-B. SDS Gel Electrophoretic Patterns of RCAM-11S and Reduced Fractions in Fig. 7.

RCAM-11S (i), F-II (h), F-III (g) and F-IV (f).

during the purification of $11 \mathrm{~S}$ globulin by the action of $0.01 \mathrm{M} 2-\mathrm{ME}$ in the buffers for the purification.

\section{DISCUSSION}

Catsimpoolas et al. ${ }^{1)}$ supposed that the $11 \mathrm{~S}$ globulin molecule consisted of two identical monomers having the three kinds of acidic and the three kinds of basic subunits. However, the present results showed that the four kinds of acidic $\left(A_{1}, A_{2}, A_{3}\right.$ and $\left.A_{4}\right)$ and the four kinds of basic $\left(B_{1}, B_{2}, B_{3}\right.$ and $B_{4}$ ) subunits presented in the molar ratio of $1: 1: 2: 2$ respectively in the $11 \mathrm{~S}$ globulin molecule, and that disulfide bonds participated in the linkage of the acidic and the basic subunits in the molar ratio of $1: 1$. Although, the two acidic subunits $A_{1}$ and $A_{2}$, and also the two basic subunits $B_{1}$ and $B_{2}$ showed the very similar chromatographic and electrophoretic behaviours, it is unlikely that these subunits are artifacts resulted from the action of proteolytic enzymes or the chemical modification during purification, because the same two acidic and the same two basic subunits were shown to be present in freshly prepared $8 \mathrm{M}$ urea $-0.2 \mathrm{M} 2-\mathrm{ME}$ extracts of soybean meals on the disc and on the acidic gel electrophoresis in $7 \mathrm{M}$ urea (unpublished 
results). The electrophoretic behaviours and the molecular weights of the fractionated intermediary subunits in the absence of reducing agents in $7 \mathrm{M}$ urea or $0.1 \%$ SDS solutions can only explained by postulating that the acidic and the basic subunits are linked by disulfide bonds in the approximate molar ratio of $1: 1$ in the $11 \mathrm{~S}$ globulin molecule. Although, the presence of disulfide bonds in protein can lead to erronous molecular weights estimated by SDS gel electrophoresis, the molecular weights of IS -1 , IS-2 and IS-3 $(58,000,60,000$ and 63,000 respectively) were in a relatively good agreement with the corresponding combined molecular weights of a pair of the acidic and the basic subunits and with the molecular weight $(61,000)$ of $11 \mathrm{~S}$ globulin determined by sedimentation equilibrium in $6 \mathrm{M}$ guanidium hydrochloride solution adjusted to $\mathrm{pH} 2$ with $1 \mathrm{~N} \mathrm{HCl}$ (unpublished result).

Very recently, Badley et al. ${ }^{\text {s) }}$ reported that they succeeded in the preparation of the $11 \mathrm{~S}$ protein which did not give the faster running component (the monomer of 11S globulin) on the polyacrylamide gel in Ornstein-Davis electrophoretic system ( $\mathrm{pH}$ 8.9). However, we observed that the $11 \mathrm{~S}$ globulin purified with ConA-Sepharose $4 \mathrm{~B}$ and Sepharose $6 \mathrm{~B}$ from the Wolf's fraction VI showed a single symmetrical peak on a Sepharose 6B column equilibrated with $1 \mathrm{M} \mathrm{KH}_{2} \mathrm{PO}_{4}$ buffer ( $\left.\mathrm{pH} 7.6\right)$ containing $0.01 \mathrm{M}$ 2-ME (their gel chromatographic buffer), and that $11 \mathrm{~S}$ protein eluted in a middle part of the single peak dialyzed against the $\mathrm{pH} 7.6$ standard buffer gave two electrophoretic bands, the dimer band (major) and the monomer band (minor) as reported previously $^{3)}$ on the ordinary polyacrylamide gel ( $\mathrm{pH}$ 8.9). We can not evaluate clearly their results, because our purification procedure is different from theirs and they have not reported the yield of the $11 \mathrm{~S}$ protein obtained by their method. The $11 \mathrm{~S}$ globulin purified by our method at least showed a dissociation reaction as an intrinsic property at a slightly alkaline $\mathrm{pH}$ at a low ionic strength as observed by Wolf et al. ${ }^{10)}$ in sedimentation. Thus, we agree that the most stable form of $11 \mathrm{~S}$ globulin is the dimer form as suggested by Catsimpoolas et al. ${ }^{1)}$

From the above results and the discussion, it is proposed that $11 \mathrm{~S}$ globulin consists of two similar, but not identical monomers; either monomer containing three intermediary subunits consists of one mole of either $A_{1}$ or $A_{2}$, one mole of $A_{3}$, one mole of $A_{4}$, one mole of either $B_{1}$ or $B_{2}$, one mole of $B_{3}$ and one mole of $\mathrm{B}_{4}$. Thus, the dimer (11S globulin molecule) should exhibit a molecular weight of 362,000 due to the molecular weights of the intermediary subunits estimated by SDS gel electrophoresis, or a molecular weight of 373,000 due to the subunit molecular weights estimated by SDS gel electrophoresis." These values are in a relatively good agreement with the value of $363,000^{11}$ reported.

The presence of at least six disulfide bonds in the $11 \mathrm{~S}$ globulin molecule indicates that disulfide bonds also participate to maintain the subunit structure of $11 \mathrm{~S}$ globulin in addition to hydrophobic, electrostatic and hydrogen bonds. A dissociation scheme for $11 \mathrm{~S}$ globulin is proposed as follows;

$$
\begin{gathered}
\text { Urea or SDS } \begin{array}{c}
\text { Intermediary subunit } \\
\text { Urea or SDS }
\end{array}\left(\mathrm{A}_{1} \mathrm{~B}_{3}+\mathrm{A}_{2} \mathrm{~B}_{3}+\mathrm{A}_{3} \mathrm{~B}_{1}+\mathrm{A}_{3} \mathrm{~B}_{2}+2 \mathrm{~A}_{4} \mathrm{~B}_{4}\right) \\
\left(\mathrm{A}_{1}+\mathrm{A}_{2}+2 \mathrm{~A}_{3}+2 \mathrm{~A}_{4}\right. \\
+\mathrm{ME}
\end{gathered} \quad \begin{aligned}
& \left.+\mathrm{B}_{1}+\mathrm{B}_{2}+2 \mathrm{~B}_{3}+2 \mathrm{~B}_{4}\right)
\end{aligned}
$$

Wright and Boulter ${ }^{12)}$ proposed the similar intermediary subunits for the lugumin of Vicia faba (broad bean) from the comparison of the SDS gel electrophoretic patterns of reduced and unreduced legumin. However, the finding in this report that each acidic subunit (polypeptide chain) linked with the specific partner of the basic subunit (polypeptide chain) through disulfide bridges is the first example in storage proteins of legume seeds.

It will be interesting to study the mechanism by which the intermediary subunits are formed and assembled into the $11 \mathrm{~S}$ globulin during seed development. 


\section{REFERENCES}

1) N. Catsimpoolas, FEBS Lett., 4, 259 (1969).

2) K. Kitamura and K. Shibasaki, Agr. Biol. Chem., 39, 945 (1975).

3) K. Kitamura, K. Okubo and K. Shibasaki, ibid., 38, 1083 (1974).

4) K. Okubo, A. B. Waldrop, G. A. Iacobucci and D. V. Myers, Cereal Chem., 52, 263 (1975).

5) W. J. Wolf, G. E. Babcock and A. K. Smith, Arch. Biochem. Biophys., 99, 265 (1962).

6) K. Weber and M. Osborn, J. Biol. Chem., 244, 4406 (1969).
7) N. Catsimpoolas, T. G. Campbell and E.W. Meyer, Arch. Biochem. Biophys., 131, 577 (1969).

8) O. H. Lowry, N. H. Rosebrough, A. L. Farr and R. J. Randal, J. Biol. Chem., 193, 265 (1951).

9) R. A. Badley, D. A. Tkinson, H. Hauser, D. Oldami, J. P. Green and J. M. Stubbs, Biochim. Biophys. Acta, 412, 214 (1975).

10) W. J. Wolf and D. R. Briggs, Arch. Biochem. Biophys., 76, 377 (1958).

11) W. J. Wolf and D. R. Briggs, ibid., 85, 186 (1959).

12) D. R. Wright and D. Boulter, Biochem. J., 141, 413 (1974). 